\title{
Pengembangan CD Game Pembelajaran Kesehatan Reproduksi untuk Meningkatkan Kesadaran
} Gender Siswa

\author{
Iman Ahmad Ihsanuddin ${ }^{6}$ \\ sabax27@gmail.com
}

\begin{abstract}
Learning games is important to be used by teachers to make the learning process in the classroom more interesting. Teachers should be able to provide innovative, creative and interesting learning so that students can be motivated and impressed by the material presented. Reproductive health learning needs more intentions and effort to be successful. The use of appropriate learning media can positively help this problem. The purpose of this study is to develop reproductive health learning games to increase gender awareness of junior high school students. The development method used in this study is ADDIE. Analysis, Design, Development, Implementation, and Evaluation are used as stages in conducting research. Qualitative and quantitative descriptive methods are used as data analysis techniques. The results showed a significant improvement of students' gender awareness from the pre-test with an average of 2.45 to 3.84 in the post-test. It can be interpreted that using learning games on reproductive health learning materials can increase gender awareness of junior high school students.
\end{abstract}

Keywords: Learning games, Reproductive health, gender awareness

${ }^{6}$ Alumni Magister Teknologi Pendidikan Universitas Sebelas Maret 


\section{PENDAHULUAN}

S umber daya manusia yang berkualitas dapat tercapai dan tercipta melalui pendidikan yang berkualitas. Sejalan dengan itu proses mendapatkan pengetahuan dan keterampilan melalui pendidikan adalah suatu bentuk investasi Sumber Daya Manusia dan bukan sebagai kegiatan konsumtif. Investasi Sumber Daya Manusia melalui pendidikan dapat diharapkan menjadi sebuah kegiatan yang permanen dan terus berkembang serta dapat menghasilkan manusia-manusia yang terampil serta dapat memiliki kemampuan yang meningkat. Sehingga kemampuan dan keterampilan tersebut dapat berguna bagi kehidupan manusia di masa depan. Kemampuan dan keterampilan dapat terbentuk melalui kegiatan belajar (Ali, 2009). Belajar merupakan kegiatan bagi setiap orang. Pengetahuan keterampilan, kebiasaan, kegemaran dan sikap seseorang terbentuk, di modifikasi dan berkembang disebabkan belajar. Karena itulah kemampuan dan keterampilan yang terbentuk dalam kegiatan belajar dapat terbentuk dengan baik dan dapat dihasilkan melalui pendidikan yang berkualitas. Indikasi pendidikan yang berkualitas serta tepat sasaran dapat tercapai apabila tujuan pembelajaran dapat tercapai. Tujuan pembelajaran bisa tercapai dengan optimal apabila komponen pengajaran tersedia. Salah satu faktor tercapainya tujuan pembelajaran dapat dipengaruhi oleh komponen pengajaran yang baik (Hudoyo, 2017).

Guru sebagai poros keberhasilan proses belajar yang selalu mengeluti, memfikirkan dan menkonstruksi proses pembelajaran dan diharapkan mampu memberikan proses pembelajaran yang aktif adalah dengan memberikan sebuah konsep pembelajaran yang menarik. Konsep pembelajaran yang menarik dan dapat membuat siswa lebih aktif adalah dengan menggembangkan media pembelajran yang lebih menarik. Media merupakan salah satu faktor penentu keberhasilan pembelajaran. Melaalui media proses pembelajaran bisa lebih menarik dan menyenagkan (joyfull learning), misalnya siswa yang memiliki ketertarikan terhadap warna maka dapat diberikan media dengan warna yang menarik. Begitu juga halnya dengan siswa yang senang berkreasi selalu ingin menciptakan bentuk atau objek yang diinginkannya, siswa tersebut dapat diberikan media yang sesuai, seperti plastisin, media balok bangun ruang, atau diberikan media gambar lengkap dengan catnya. Dengan menggunakan media berteknologi seperti halnya komputer, sangat membantu siswadalam belajar, seperti belajar berhitung, membaca dan memperkaya pengetahuan.

Program permainan (game) pada komputer banyak yang berisi tentang pembelajaran yang dikemas sangat menyenangkan buat siswa, sehingga siswa seolah tidak merasa sedang belajar. Aspek penting lainnya penggunaan media adalah membantu memperjelas pesan pembelajaran. Informasi secara lisan terkadang tidak dipahami sepenuhnya oleh siswa, terlebih apabila guru kurang cakap dalam menjelaskan materi. Disinilah peran media, sebagai alat bantu memperjelas pesan pembelajaran (Burgos,2008). Informasi kepada peserta didik belum dapat diberikan secara konkrit, menjadi kendala dalam pencapaian tujuan pembelajaran. Hal tersebut dikarenakan guru masih menggunakan metode pembelajaran konvensional dalam menyampaikan informasi yaitu ceramah. Hasil studi pendahuluan di dua sekolah menengah pertama yang tecatat sebagai sekolah yang menduduki peringkat kurang baik berdasarkan dari data dinas pendidikan Wonosobo, ditemukan bahwa materi pembelajaran yang disampaikan guru, masih menggunakan cara memberikan gambar dan teoritis sesuai dengan modul guru, bukut paket, LKS, dan alat praga tanpa ada pengembangan ke model pembelajaran yang lebih kreatif. Dari permasalahan pada studi pendahuluan tersebut, didapatkan peserta didik yang mengalami multi tafsir, belu, dapat mengetahui kebenaran yang terkait dengan teori, dan belum mampu memvisualisasikan teori yang disampaikan oleh guru.

Hal inilah yang menjadi, antisipasi yang harus diperhatikan, pasalnya permasalahan tersebut timbul pada materi kesehatan reproduksi, sehingga dapat menimbulkan beberapa masalah, seperti peserta didik akan mengingat materi yang peserta didik tafsirkan tanpa tahu kebenaran dan akan melekat kepada diri peserta didik, selain itu karena informasinya masih banyak penggunaan bahasa asing, bahasa 
istilahlah dan guru belum dapat memaparkan visual yang ada, karena masih dianggap tabu untuk diberikan, menjadikan pemahaman peserta didik terhadap kesehatan reproduksi berdampak pada kurangnya kesadaran peserta didik terhadap gender yang mereka miliki.

Mata pelajaran Biologi merupakan salah satu bidang studi yang diajarkan pada jenjang pendidikan dasar tingkat Sekolah Menengah Pertama (SMP). Sesuai dengan peraturan pemerintah nomor 35 tahun 2013 bahwa bahan kajian ilmu pengetahuan alam, anata lain fisika, biologi dan kimia dimaksudkan untuk mengembangkan pengetahuan, pemahaman, dan kemampuan analisis peserta didik terhadap lingkungan alam dan sekitarnya. Atas dasar tersebut, pembelajaran biologi pada tingkatan ini juga dilaksanakan prinsip-prinsip pembelajaran yang sesuai dengan Permendikbud no 22 tahun 2016 tentang standar proses pendidikan dasar dan menengah, sesuai dengan standar kompetensi lulusan atau SKL dan standar isi atau SI, terdapat 14 prinsip pembelajaran yang harus digunakan dalam penyelenggaraan proses pembelajaran dikelas. Prinsip pembelajaran yang tertera adalah prinsip pembelajaran dari guru sebagai satu - satunya sumber belajar menjadi belajar berbasis aneka sumber belajar, dari pendekatan tekstual menuju proses sebagai penguatan penggunaan pendekatan ilmiah, dan memanfaatkan teknologi informasi dan komunikasi untuk meningkatkan efisiensi dan efektivitas pembelajaran.

Hasil dari studi pendahuluan yang dilakukan dengan cara wawancara dan dokumentasi pada guru pengampu materi kesehatan reproduksi di sekolah yang tercatat sebagai sekolah yang memiliki peringkat kurang bai di Wonosobo, bahwa guru tersebut masih senang meggunakan metode ceramah. Dua guru menganggap tersebut, masih penting pada pembelajaran yang dapat berjalan sesuai waktu yang ada dan siswa sendiri dirasa sudah cukup memahami buku modul, buku paket, serta LKS yang sebagai buku materi pegangan siswa. Melihat gerakan dari guru tersebut, ternyata belum tergerak untuk memanfaatkan sarana yang ada disekolah sebagai alat pendukung penerapan pembelajaran yang moderen dengan memanfaatkan LCD projector, laburaturium komputer, speaker dan leptop yang ada sebagai media pembelajaran yang menarik.

Sementara hasil studi pendahuluan pada kegiatan pembelajaran pada materi kesehatan reproduksi adalah (a) Ditemukannya peserta didik yang masih belum dapat menerima informasi secara utuh, mengenai istilah-istilah bahasa latin dalam kesehatan reproduksi yang berakibat pada pengucapan dan penyebutan bahasa asing yang belum tepat. Selain itu gambar atau visualisasi yang diberikan oleh guru kepada siswa membuat waktu pembagian menjadi dimanfaatkan oleh siswa untuk bermain dan gambar yang diberikannya belum dapat menarik minat siswa untuk memperhatikan. Artinya kondisi kegiatan pembelajaran didalam kelas belum kondusif. (b) Materi yang diberikan oleh guru belum dapat terintegrasi dengan dunia nyata, sehingga mengakibatkan siswa menjadi bingung dan bosan bahkan tidak tertarik untuk mengikuti pelajaran tersebut, terlihat dengan adanya siswa yang cenderung diam didalam kelas. (c) Metode ceramah yang diterapkan oleh guru membuat pembelajaran terpusaat pada guru, sehingga siswa hanya dapat mendengarkan, memahami, dan melihat gambar yang diberikan oleh guru.

Dampak yang dialami oleh siswa adalah (a) kurangnya minat belajar yang diakibatkan metode pembelajaran yang kurang menarik diterapkan oleh guru. (b) keadaan kelas yang belum kondisif, terlihat saat guru sedang memberikan materi dengan metode ceramah, siswa terlihat banyak yang bercanda bersama temannya. (c) Istilah asing dan teori yang harus siswa pahami, membuat siswa harus lebih fokus mendengarkan dan menghafalkan serta dapat mengilustrasikan sendiri terhadap pemahaman yang mereka tangkap.

Akses internet dan fasilitas yang mendukung untuk proses pembelajaran yang modern, ternyata terhambat oleh kurangnya kompetensi dan penguasaan teknologi informasi pada guru. Terlebih mindset guru yang nyaman, rileks dan ingin cepat dalam menggunakan metode pembelajaran ceramah dibanding dengan menyiapkan media pembelajaran yang menarik, hal tersebut ternyata berdampak pada rendahnya kesadaran gender peserta didik. Melihat dari persentase hasil belajar terdapat $55 \%$ siswa 
mencapai standar dan $45 \%$ belum dapat mencapai standar. Artinya pengetahuan terhadap kesehatan reproduksi pada siswa sudah lumayan, namun sinkronisasai dengan kesadaran gender yang meraka miliki masih perlu untuk ditingkatkan. Pasalnya, pengujian yang diberikan hanyalah seputar materi hafalan terkait istilah, belum pada tahap implementasi pada dunia nyata. Hal itulah menjadi permasalah pokok bagi siswa.

Penggunaan media pembelajaran yang sederhana dan menarik perhatian dan dapat diterapkan oleh guru secara mudah adalah media pembelajaran game pembelajaran. Selain dapat dipadukan dengan metode ceramah, media ini dapat memberikan motivasi pembelajaran kepada siswa (Darmadi, 2017). Kemudahan dan adanya animasi pendorong minat siswa membuat pembelajaran lebih menarik, selain itu video yang realistis dan permainan seru dapat diterapkan dalam game pembelajaran. Sehingga siswa dapat muda memahami, mengintergasikan dengan dunia nyata.

Dari hasil penelitian yang menyatakan bahwa permainan edukatif penting manfaatnya ialah:

"The use of educational games in learning environments is an increasingly relevant trend. The motivational and immersive traits of game-based learning have been deeply studied in the literature, but the systematic design and implementation of educational games remain an elusive topic. In this study some relevant requirements for the design of educational games in online education are analyzed, and a general game design method that includes adaptation and assessment features is proposed. Finally, a particular implementation of that design is described in light of its applicability to other implementations and environments" (Burgos,2008).

Artinya bahwa penggunaan permainan edukatif di lingkungan belajar merupakan tren yang semakin relevan. Karakter motivasional dan immersive dari pembelajaran berbasis game telah dipelajari secara mendalam dalam literatur, namun rancangan dan pelaksanaan sistematis permainan pendidikan tetap menjadi topik yang sulit dipahami. Dalam studi ini beberapa persyaratan yang relevan untuk desain permainan pendidikan dalam pembelajaran online dianalisis, dan metode perancangan permainan umum yang mencakup fitur adaptasi dan penilaian diusulkan. Akhirnya, implementasi desain tertentu dijelaskan sehubungan penerapannya terhadap implementasi dan lingkungan lainnya.

Dari pendapat diatas dapat diartikan bahwa dengan game pembelajaran yang tersusun secara tersetruktur, desain game pembelajarn yang sesuai dan runtut dapat memberikan point plus bagi kualitas game pembelajaran. Game pembelajaran yang menarik sesuai dengan tujuan pembelajaran sehingga setiap tupoksi yang ingin disampaikan dapat tepat sasaran. Selain itu aktifitas bermain dapat diterapkan dalam pembelajaran, sehingga siswa akan merasa bermain padahal siswa tersebut sedang belajar. Game pembelajaran dirasa dapat dijadikan alternatif dalam pemanfaatan pembelajaran sebagai penunjang aktifitas pembelajaran dikelas.

Game pembelajaran yang dikembangkan dalam penelitian ini adalah game pembelajaran kombinasi antara wilayah atletik game dengan permainan komputer. Selain itu game pembelajaran ini dikembangkan melalui komputer dengan software yang compatible dengan berbagai macam jenis komputer. Alasan dari pengembangan game pembelajaran ini berasal dari mayoritas siswa senang dengan atletik dan senang bermain game, sehingga pengembangan ini diarahkan kepada permainan komputer atletik. Selain itu game pembelajaran dapat menghadirkan suasana yang menyenangkan, humoris dan santai, namun tidak meninggalkan unsur materi yang menjadi aspek utama.

Oleh sebab permasalahan tersebut yang mendasari untuk melakukan penelitian yang berjudul pengembangan game pembelajaran kesehatan reproduksi pada mata pelajaran biologi dengan menggunakan CD di Sekolah Menengah Pertama Kabupaten Wonosobo.

Multimedia adalah pemanfaatan komputer untuk membuat dan menggabungkan teks, grafik, audio, gambar bergerak (video dan animasi) dengan menggabungkan link dan tool yang memungkinkan pemakai melakukan navigasi, berinteraksi berkreasi dan komunikasi (Loosemore, 2010). Selain itu 
pengertian multimedia adalah sebuah media yang menggabungkan berbagai jenis media lain, misalnya penggabungan visual dan auditori. Dengan media seperti ini, hampir setiap orang menjadi lebih mudah untuk menerima sebuah informasi. Salah satu bentuk multimedia adalah animasi yang memadukan gambar dan suara.

Komponen Multimedia, juaga sebagai menegas bahwa multimedia harus memiliki komponen. Terkandung empat komponen penting dalam multimedia. Pertama, harus ada komputer yang mengkoordinasikan apa yang dilihat dan didengar, yang berinteraksi dengan kita. Kedua, harus ada link yang menghubungkan kita dengan informasi. Ketiga, harus ada alat navigasi yang memandu kita, menjelajah jaringan informasi yang saling terhubung. Keempat, multimedia menyediakan tempat kepada kita untuk mengumpulkan, memproses, dan mengkomunikasikan informasi dan ide kita sendiri. Dari beberapa pengertian multimedia diatas dapat ditarik garis bawah, bahwa multimedia adalah gabungan beberapa alat seperti: video, audio, gambar, animasi, teks, seni, dan juga bisa terdapat navigasi untuk menyampaikan informasi. Sedangkan komponen multimedia yang diperlukan dari sistem multimedia meliputi kamera, video recorder, personal komputer, media penyimpanan, dan lain-lain (Hofstette, 2017).

Game pembelajaran juga dapat disebut dengan game edukasi. Game pembelajaran ini pada era sekarang sudah menjadi trobosan dalam media pembelajaran untuk memberikan stimulus ingatan dengan jangka panjang terhadap siswanya. Game edukasi sebagai sebuah game yang bertujuan menyelesaikan permainan dan mencapai proses pembelajaran. Tujuan desain game edukasi adalah untuk mendukung isi pembelajaran di lingkungan permainan. permainan menjadi lima wilayah utama, yaitu permainan papan, permainan kartu, atletik game, permainan anak - anak dan permainan komputer dan termasuk edukasi game di dalam gadget. dalam batasan-batasan ini, maka gadget masih memberikan manfaat positif bagi anak (Wijanarko \& Setiawati, 2016). Bermain yang mampu melatih kreativitas anak adalah bermain dengan cara membangun atau menyusun. Sedangkan permainan melalui gadget, minim akan hal ini. Seandainya ada, maka hanya melalui gambar (menyusun puzzel, warna, matching dII), bukan membangun atau menyusun secara tiga dimensi seperti balok - balok, lego dIl. yang paling nyata adalah dengan menggunakan gadget selama 3-5 jam perhari, maka anak - anak kehilangan waktu dan semangat untuk bermain, padahal permainan adalah cara dan media anak untuk membangun kecerdasannya. Selain itu juga terdapat pengertian bahwa Game pembelajaran merupakan sesuatu yang menyenagkan dan dekat dengan anak didik. Penggunaan game bertujuan untuk mengurangi tingkat kejenuhan mereka terhadap pelajaran (Davidson, 2013).

Dari pengertian diatas maka dapat digaris bawahi, bahwa game pembelajaran adalah media pembelajaran modern yang mampu mengemas teks, gambar, video, dan audio dapat dikontrol dan digerakan, sehingga dapat digunakan untuk proses pembelajaran yang menarik.

\section{Kesehatan Reproduksi}

Secara sederhana, reproduksi berasal dari kata re yang berarti kembali dan production yang berarti membuat atau menghasilkan, jadi reproduksi (reproduction) mempunyai arti suatu proses kehidupan manusia dalam menghasilkan keturunan demi kelestarian hidup. Kesehatan reproduksi adalah keadaan sejahtera fisik, mental, dan sosial yang utuh dalam segala hal yang berkaitan dengan fungsi, peran dan sistem reproduksi. Arti kesehatan reproduksi adalah suatu kondisi sehat yang menyangkut sistem, fungsi, dan proses reproduksi yang dimiliki oleh seseorang. Pengertian sehat di sini tidak semata - mata bebas dari penyakit atau kecatatan, namun juga sehat secara mental dan sosial-kultural (Peterson, 2013).

Kesehatan Reproduksi dalam Mata Pelajaran Biologi, Pengetahuan kesehatan reproduksi dirasa sangat dibutuhkan. Kesenjangan yang masih dirasakan saat ini adalah belum masuknya pendidikan seksualitas dan reproduksi yang komprehensif ke dalam kurikulum pendidikan nasional (Gerakan Kesehatan Ibu dan Anak, 2016). Dari beberapa pengertian diatas dapat digaris bawahi bahwa kesehatan reproduksi adalah suatu kondisi sehat sistem organ, fungsi organ, fisik, mental dan sosial seseorang baik laki-laki maupun perempuan. 


\section{Gender}

"Gender is a 'complex of socially guided perceptual and interactional and micropolitical activities that cast particular pursuits as expressions of masculine and feminine "natures" and as such is a routine accoplishment. Note the distinction between gender, sex categorization, and sex. Sex is understood to be the application of biological criteria, which has been socially agreed upon" (Kumra, Simpson, \& Burke, 2014)

Pengertian diatas dapat diartikan sebagai berikut Gender merupakan sebuah aktivitas perseptual dan interaksi yg kompleks dan mikropolitik yang terpandu secara sosial yang mengarahkan pada pencarian tertentu sebagai ungkapan "sifat" maskulin dan feminin dan merupakan sebuah rangkaian yg berulang terus. Perhatikan perbedaan antara gender, pengelompokan jenis kelamin dan seks. Seks dipahami sebagai penerapan kriteria biologis, yang disepakati secara social (Rokhmansyah, 2016). Gender adalah suatu sifat yang melekat pada laki-laki maupun perempuan dikonstruksi secara sosial maupun kultural.

Gender merupakan/perbedaan yang tampak pada laki - laki dan wanita berdasarkan nilai - nilai dan tingkah laku yang dilakukan keduannya. Misal perempuan dikenal lemah lembut, cantik emosional, keibuan, sedangkan laki - laki sebaliknya, dianggap kuat, rasional, jantan dan perkasa. Dengan demikian gender merupakan konstruksi sosial budaya, terhadap perbedaan jenis kelamin laki - laki dan perempuan, yang berbeda pengertian seks/jenis kelamin. Beberapa pendapat diatas dapat digaris bawahi bahwa gender merupakan sifat laki-laki ataupun perempuan yang terbangun berdasarkan lingkungan sosial dan budaya yang menjadikan perilaku dan nilai-nilai baik laki-laki maupun perempuan (Manu et al, 2016).

Pemahaman dan konsep gender merupakan salah satu awal mulanya terbentuknya kesadaran gender. Karena ketika seseorang memahami apa itu gender dan konsep gender maka seseorang tersebut memiliki kesadaran akan gender. Cara pandang pengarusutamaan merupakan strategi untuk memasukkan gender dalam kebiasaaan dan mekanisme yang berjalan di masyarakat, caranya dengan memasukkan secara sadar pemahaman gender. Seperti halnya kurikulum gender merupakan cara pengarusutamaan pada organisasi untuk mendidik tentang pengetahuan gender. Gender sebagai pengetahuan adalah bagian dari pendidikan modern. Kebijakan pengarusutamaan gender adalah bagian dari kebijakan yang sudah ada di Indonesia, melalui instruksi Presiden RI No. 9 tahun 2000 tentang pengarusutamaan gender dalam pembangunan nasional, instruksinya antara lain: "Melaksanakan pengarusutamaan gender guna terselenggaranya perencanaan, penyusunan, pelaksanaan, pemantauan dan evaluasi atas kebijakan dan program pembangunan nasional yang berperspektif gender sesuai dengan bidang tugas dan fungsi, serta kewenangan masing - masing". Pemahaman tentang gender hendaknya diperjelas sehingga penangkapan seseorang tidak menuai hal yang rancu antara pemahaman gender dan pemahaman seks.

Perbedaan gender dan seks adalah: (1) Seks adalah pembagian jenis kelamin yang ditentukan secara biologis dan karena itu melekat pada jenis kelamin tertentu misalnya alat reproduksi pria punya penis, bersperma, berkumis dll. Sedangkan perempuan merupakan manusia yang memiliki alat reproduksi telur (ovum), bervagina dan menyusui. Semua perbedaan itu secara biologis melekat pada individu selamanya sehingga fungsinya tidak dapat dipertukarkan. Secara permanen tidak berubah dan merupakan ketentuan biologis ataupun merupakan ketentuan Tuhan yang bersifat Kodrati. (2) Gender adalah pembagian atau pembedaan kategori pria dan wanita yang dikonstruksi secara kultural. Gender sebagai pembedaan antara perempuan dan laki-laki yang dibuat masyarakat. Dapat berubah, dipengaruhi oleh budaya, agama dan Negara. Sehingga dapat dipertukarkan. Pembedaan peran yang dikonstruksikan secara sosio kultural dengan dasar kesepakatan masyarakat. Dari penjelasan diatas dapat ditekankan bahwa pemahaman dan konsep gesnder merupkan perbedaan yang lebih baik. 


\section{METODE PENELITIAN}

Penelitian dan pengembangan ( $R$ \& $D)$ adalah suatu penelitian dimana alat yang telah kita buat diujicobakan dan dilihat tingkat keefektifannya (Maturidi, 2012). Jenis penelitian yang digunakan dalam penelitian ini, merupakan jenis penelitian pengembangan yang digunakan untuk mengembangkan produk berupa game pembelajaran kesehatan reproduksi menggunakan CD pada mata pelajaran Biologi untuk Kelas VIII SMP/Mts. Produk ini diharapkan mampu meberikan informasi secara lengkap terkait pengetahuan tentang kesehatan reproduksi, memberikan trobosan media pembelajaran sesuai dengan karakteristik gaya belajar siswa, dan dapat membantu guru dalam menyampaikan informasi.

Prosedur penelitian yang digunakan dalam penelitian ini menggunakan model pengembangan ADDIE. Model ADDIE adalah model pengembangan yang dipopulerkan pada tahun 1990-an oleh Reiser dan Mollenda. Dimana model pengembangan ADDIE merupakan singkatan dari Analysis, Design, Development, Implementation, Evaluation (Sutarti \& Irawan, 2017). Penjelasan dari masing - masing tahapan tersebut adalah sebagai berikut: (a) Analisis, Dalam analisis terdapat 2 studi yang harus dilakukan antara lain: Pertama studi pendahuluan, studi pendahuluan ini dilakukan survai kepada 2 guru mata pelajaran biologi yang berbeda sekolahan di Kabupaten Wonosobo.

Pengambilan data dalam tahap studi pendahuluan ini menggunakan wawancara dan observasi. Wawancara yang dilakukan untuk mengetahui pemakaian media pembelajaran oleh guru, melihat proses pembelajaran Biologi, mengamati hasil belajar siswa dan untuk mengetahui bentuk bahan ajar Biologi yang digunakan. Observasi dilakukan untuk mengetahui kondisi pembelajaran Biologi di kelas. Data dari hasil wawancara dan observasi, berguna untuk memperoleh informasi terkait permasalahan, kebutuhan peserta didik serta sebagai solusi yang tepat untuk mengatasi sebuah permasalahan. Kedua, Studi pustaka, studi pustaka ini dilakukan untuk mengkaji teori dari hasil penelitian yang relevan sesuai dengan potensi dan kebutuhan pengembangan. Selain itu studi pustaka dilakukan untuk menjadi sebuah landasan ilmiah dari sebuah produk yang nanti akan dihasilkan.

Dalam penelitian ini, pada tahap analisis (analyze) meliputi kegiatan sebagai berikut: (1) melakukan analisis kompetensi yang di tuntut kepada peserta didik, dalam hal ini materi kesehatan reproduksi. (2) melakukan analisis karakteristik peserta didik tentang, pengetahuan, keterampilan, dan gaya belajar yang telah dimiliki peserta didik serta aspek yang terikat. (3) Melakukan analisis materi sesuai dengan tuntuan kompetensi. (4) Melakukan analisis materi kedalam game pembelajaran, sehingga terlihat lebih interaktif. (5) Melakukan analasis sepesifikasi komputer yang akan digunakan unuk pengembangan game pembelajaran. (b) Desain, pada tahapan perancangan (Design), tahapan ini dilakukan berdasarkan kerangka acuan sebagai berikut: (1) Untuk siapa game pembelajaran dirancang? dalam hal ini game pembelajaran diperuntukan untuk peserta didik jenjang sekolah menengah pertama. (2) Kemampuan yang diinginkan untuk dipelajari? dalam hal ini kemampuan yang diinginkan merupakan kemampuan peserta didik dalam memahami kesehatan reproduksi sehingga dapat meningkatkan pemahaman gender. (3) Bagaimana materi pelajaran dapat diterapkan dalam game pembelajaran dengan baik? materi pelajaran kesehatan reproduksi di rancang secara interaktif dan mudah dipahami oleh peserta didik.

STORY BOARD GAME PEMBELAJARAN KESEHATAN REPRODUKSI
"TENDANGAN RERE"
\begin{tabular}{|l|l|l|l|l|}
\hline No & Nomer Room & Keterangan Room & \multicolumn{1}{|c|}{ Bentuk } & \multicolumn{1}{c|}{ BS } \\
\hline 1 & Room 1 & Halaman home & $\begin{array}{l}\text { Persegi dan ada } \\
\text { tombol navigasi }\end{array}$ & $\begin{array}{l}\text { Garuda } \\
\text { didadaku }\end{array}$ \\
\hline 2 & Room 2 & Halaman Petunjuk & $\begin{array}{l}\text { Persegi, tombol } \\
\text { navigasi, text form } \\
\text { yang menjelaskan } \\
\text { petunjuk }\end{array}$ & $\begin{array}{l}\text { Garuda } \\
\text { didadaku }\end{array}$ \\
\hline
\end{tabular}


(4) Bagaimana game pembelajaran dapat menentukan tingkat penguasaan kesehatan reproduksi pada mata pelajaran biologi yang sudah di capai sehingga pemahaman siswa terkait dengan gender meningkat. Dalam hal ini game pembelajaran dapat disajikan tempat asesmen dan evaluasi. (5) Alure yang digunakan dalam game pembelajaran ini di susun sesuai dengan flowchart game pembelajaran antara lain: start, materi (dalam bentuk video interaktif), materi dalam game pembelajaran, dan uji pemahaman.

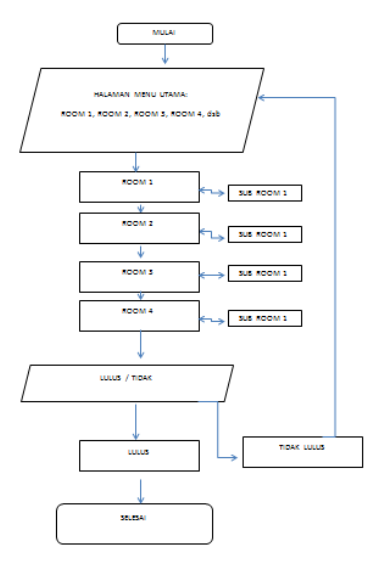

Gambar 2. Flowchart game pembelajaran

(c) Pengembangan, tahap pengembangan (development) meliputi kegiatan pengumpulan bahan Imateri game pembelajaran kesehatan reproduksi, pengumpulan bahan terkait dengan gender, pengumpulan bahan materi tentang pemahaman kesehatan reproduksi dapat meningkatkan pemahaman gender, pembuatan karakter game pembelajaran, pembuatan layout desain dalam game pembelajaran, pembuatan audio / instrument musi dalam game pembelajaran, pembuatan gambar - gambar ilustrasi, pembuatan video pendek terkait tentang kesehatan reproduksi dan gender, pengetikan storyboard, pengetikan naskah video dan game pembelajaran, serta konten - konten pendukung game pembelajaran. Kemudian kegiatan penyusunan game pembelajaran dengan software komputer dapat dilakukan.

Dalam tahapan pengembangan ini, pembuatan produk awal, Game pembelajaran dibuat sesuai dengan desain yang telah direncanakan. Game pembelajaran dibuat menggunakan komputer dengan menggunakan bantuan software aplikasi utama Microsoft Offiice Power Point 2010, Corel Draw \& Adobe Photoshop berguna untuk pembuatan gambar layout dan gambar karakter. Auda city sebagai software yang berguna untuk membuat audio dan mengubah audio. CyberLink PowerDirector 13 sebagai software pembuat konten video. Format Factory sebagai software yang berguna untuk merubah format ektensi dari sebuah file. Materi yang ditampilkan adalah cangkupan kesehatan reproduksi remaja secara gamblang. Dalam game pembelajaran yang dikembangkan nantinya terdapat latihan - latihan soal yang mendukung dari kebutuhan siswa.

Validasi Desain Produk, validitasi desain produk meliputi: Validasi materi, validitas ini bertujuan untuk penyesuaian materi dalam game pembelajaran sangatlah penting oleh sebab itu kelayakan materi dalam game pembelajaran harus dapat dikatakan valid terlebih dahulu. Tujuannya untuk mengetahui kelayakan penyajian materi dalam game pembelajaran. Validasi materi dilakukan oleh ahli materi yang merupakan praktisi pendidikan pada bidang studi biologi dan kesehatan reproduksi. Untuk mengetahui validitas materi dalam game pembelajaran digunakan instrumen pengumpulan data berupa angket kelayakan materi yang meliputi aspek kesesuaian materi, kelayakan penyajian dan kelayakan bahasa yang digunakan. Kemudian validitas selanjutnya adalah Validasi media, validasi media dilakukan oleh ahli media terkait kelayakan media yang telah dikembangkan dalam hal ini adalah Forum Multimedia Edukasi Kabupaten Boyolali (FORMULASI). 
Penilaian dilakukan menggunakan angket kelayakan media meliputi aspek tampilan, navigasi, dan prinsip multimedia pembelajaran. Revisi Desain, Produk yang telah di validasi melalui diskusi ahli, setelah itu akan didapatkan kekurangan dari produk yang dihasilkan yakni game pembejaran. Penilaian berupa masukan dan saran dari masing-masing ahli akan digunakan sebagai bahan perbaikan produk game pembelajaran. Setelah revisi desain, Uji kelayakan produk sangat diperlukan, kelayakan produk yang di ujikan bertujuan untuk menentukan kelayakan produk yang dikembangkan sebelum produk yang dikembangkan di terapkan / diimplementasikan dalam kegiatan pembelajaran yang sebenarnya. Produk dapat dinyatakan layak apabila memenuhi kriteria sangat baik. Berikut ini lembar kriteria kelayakan produk yang dihasilkan.

Tabel 1. Kriteria Kelayakan Produk

\begin{tabular}{cll}
\hline \multicolumn{1}{c}{ Interval } & Kualifikasi & Nilai \\
\hline $86 \% \leq$ skor $\leq 100 \%$ & Sangat Baik & A \\
$71 \% \leq$ skor $\leq 85 \%$ & Baik & B \\
$56 \% \leq$ skor $\leq 70 \%$ & Cukup Baik & C \\
$41 \% \leq$ skor $\leq 55 \%$ & Tidak Baik & D \\
$25 \% \leq$ skor $\leq 40 \%$ & Sangat Tidak Baik & E \\
\hline
\end{tabular}
berikut:

Dari hasil validasi masing-masing subjek kemudian dianalisis menggunakan rumus sebagai

Presentase $=\quad$ Jumlah skor yang diperoleh $\times 100 \%$

Skor Maksimal

Selanjutnya, menentukan kriteria kelayakan produk dalam keseluruhan subjek dapat digunakan rumus:

$$
\text { Presentase }=\underline{\text { Jumlah presentase semua subjek }} \times 100 \%
$$

Banyaknya subjek

(d) Implementasi, implementasi dilakukan bertujuan untuk mengukur keefektifan produk yang dikembangkan. Pada tahap ini, produk yang dikembangkan dapat diterapkan dalam pembelajaran melalui uji coba produk. Uji coba produk ini, dapat dilakukan sebanyak tiga kali, yaitu: Uji coba satu-satu, Uji coba kelompok kecil, dan Uji coba lapangan. (e) Evaluasi, Evaluasi dilakukan untuk mengetahui efektifitas penggunaan game pembelajaran. Evaluasi dapat dilakukan dalam dua cara yaitu evaluasi sumatif dan evaluasi formatif. Evaluasi formatif dilakukan untuk merevisi atau memperbaiki produk yang dikembangkan, evaluasi formatif sendiri dapat dilakukan saat proses validasi produk dan uji coba produk. Sedangkan evaluasi sumatif dapat dilakukan untuk mengukur keefektifan produk yang ditinjau dari hasil belajar dan kesadaran gender siswa. Untuk mengukur keefektifan produ dapat dilakukan melalui beberapa langkah pengujian yaitu uji normalitas, homogenitas dan uji t sampel berpasangan.

\section{HASIL DAN PEMBAHASAN}

\section{Analisis Uji Keefektifan Produk}

Analisis uji keefektifan produk dapat dilakukan dengan uji t sampel berpasangan. Uji efektifitas dapat dilakukan sebelum melakukan beberapa langkah uji prasyarat diantaranya adalah uji normalitas 
dan uji homogenitas. Uji normalitas adalah sebuah uji yang dilakukan dengan tujuan untuk menilai sebaran data pada sebuah kelompok data atau variabel, apakah sebaran data tersebut berdistribusi normal ataukah tidak. Data yang baik dan layak adalah data berdistribusi normal, oleh sebab itu uji normalitas merupakan uji prasyarat dalam melakukan analisis data. Uji homogenitas merupakan uji untuk mengetahui apakah variansi-variansi dari sejumlah populasi sama atau tidak. Uji homogenitas dilakukan pada data hasil tes dari kelompok eksperimen dan kelompok kontrol. Uji homogenitas ini untuk mengetahui apakah kelompok eksperimen dan kontrol mempunyai variansi yang sama. Uji t sample berpasangan, uji keefektifan ini bertujuan untuk menentukan sejauh mana produk yang telah dikembangkan efektif untuk meningkatkan hasil belajar. Data uji keefektifan produk di dapat dari hasil tes pretest dan posttest. Produk dapat dikatakan efektif jika terdapat perbedaan hasil belajar antara kelas eksperimen dan kelas control. Penghitungan uji keefektifan ini menggunakan uji Paired Sample t Test, adapun ketentuannya sebagai berikut: Membuat hipotesis, $\mathrm{H} 0: \mu 1=\mu 2$ (tidak ada perbedaan hasil belajar antara kelas eksperimen dengan kelas kontrol), $\mathrm{H} 1: \mu 1 \neq \mu 2$ (ada perbedaan hasil belajar antara kelas eksperimen dengan kelas kontrol), menentukan taraf signifikansi $a=0.05$, menghitung statistik

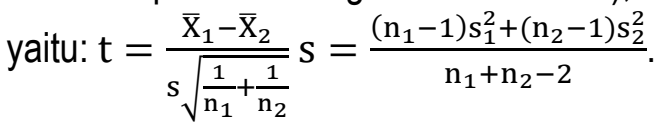

Keterangan :

$\overline{\mathrm{X}}_{1}=$ Rata-rata nilai tes kemampuan akhir siswa pada kelas eksperimen

$\overline{\mathrm{X}}_{2}=$ Rata-rata nilai tes kemampuan akhir siswa pada kelas kontrol

$\mathrm{s} 1=\quad$ Simpangan baku kelas eksperimen

s2 $=\quad$ Simpangan baku kelas kontrol

$\mathrm{n} 1=$ Banyak siswa kelas eksperimen

n2= Banyak siswa kelas kontrol

$\mathrm{s}=$ Variansi gabungan kelas eksperimen dan kontrol

d0 $=0$ (sebab tidak dibicarakan selisih rerata).

\section{Analisis tingkat kesadaran gender}

Hasil penilaian dari angket kesadaran gender akan di cari nilai rerata kemudian akan disimpulkan untuk mengetahui tingkat kesadaran gender. Adapun koversikan hasil angket dengan menggunakan skala 5 menurut Sudijono (2009) digambarkan melalui tabel di bawah ini:

Tabel 2. Pedoman Pengubahan Data Kuantitatif Menjadi Kualitatif

\begin{tabular}{ccc}
\hline Interval Skor & Nilai & Kategori \\
\hline $\mathrm{X}>4.21$ & 5 & Sangat baik \\
$3.40<\mathrm{X} \leq 4.21$ & 4 & Baik \\
$2.60<\mathrm{X} \leq 3.40$ & 3 & Cukup \\
$1.79<\mathrm{X} \leq 2.60$ & 2 & Kurang \\
$\mathrm{X} \leq 1.79$ & 1 & Sangat kurang \\
\hline
\end{tabular}

Dalam penelitan ini, Tahap evaluasi (evaluation) pada game pembelajaran, dimana evaluasi formatif dapat dilakukan untuk mengumpulkan data pada setiap tahapan sehingga dapat digunakan untuk menyempurnakan. Evalusasi sumatif juga dapat dilakukan pada akhir program untuk mengetahui pengaruhnya terhadap peningkatan pemahaman gender dan kualitas dalam pembelajaran kesehatan reproduksi. Namun dalam penelitian ini, pengembangan game pemebalajaran jenis yang diambil untuk 
evaluasi yang digunakan adalah hanya evaluasi formatif, karena jenis evaluasi ini berhubungan dengan tahapan penelitian pengembangan untuk meningkatkan efektifitas game pembalajaran yang dihasilkan.

Uji aktifitas yang dilakukan pada penelitian ini menggunakan pre test dan post tes pada dua sekolah di Wonosobo, dengan jumlah total siswa 56 , yang bertujuan untuk mengukur kesadaran gender pada siswa menggunakan angket, hasil uji tersebut adalah:

Tabel 3. Perhitungan uji t sempel berpasangan

\begin{tabular}{llrrrr}
\hline & Mean & $\begin{array}{c}\text { Std. } \\
\text { Deviation }\end{array}$ & t & df & $\begin{array}{l}\text { Sig. (2- } \\
\text { tailed) }\end{array}$ \\
\hline $\begin{array}{l}\text { Pretest }- \\
\text { Posttest }\end{array}$ & $-1,39286$ &, 94731 & $-11,003$ & 55 &, 000 \\
\hline
\end{tabular}

Berdasar dengan hasil perhitungan pada tabel perhitungan uji t berpasangan adalah dimana nilai siswa meningkat secara signifikan dari pre-test yang berawal dengan nilai rata - rata 2,45 menjadi 3, 84 pada post test. Hal tersebut dapat diartikan bahwa pembelajaran menggunakan game pembelajaran pada materi kesehatan reproduksi dapat meningkatkan kesadaran gender terhadap siswa sekolah menengah pertama di Wonosobo.

\section{KESIMPULAN}

Pengembangan game pembelajaran ini dapat dikatakan berkualitas, pasalnya game pembelajaran ini mudah dilihat, menarik, sederhana, bermanfaat dan benar atau dapat dipertanggung jawabkan. Game pembelajaran ini dibuat dengan menggunakan sotfware presentas dengan menggunakan pengembangan melalui tahap analisis kebutuhan, perancangan, produksi, uji coba, revisi, finalisasi, dan produksi masal. Game pembelajaran yang dikembangan ini, dapat diterapkan pada mata pelajaran biologi materi kesehatan reproduksi dijenjang sekolah menengah pertama.

\section{DAFTAR PUSTAKA}

Ali, M. (2009). Pendidikan untuk Pembangunan Nasional: Menuju Bangsa Indonesia yang Mandiri dan Berdaya Saing Tinggi. Jakarta: Grasindo.

Hudojo. (2017). Belajar dan Pembelajaran Modern: Konsep Dasar, Inovasi dan Teori Pembelajaran. Yogyakarta: Garudhawaca.

Burgos, D. (2008). Educational Game Design for Online Education, Computers in Human Behavior, 24(6), $2530-2540$.

Hofstetter. (2017). Pedoman Praktis Multimedia dengan Authorware 7. Yogyakarta: CV Budi Utama.

Wijanarko, J. \& Setiawati, E. (2016). Ayah Ibu Baik Parenting Era Digital: Pengaruh Gadget pada Perilaku dan Kemampuan Anak Menjadi Orang Tua Bijak di Era Digital. Jakarta: Keluarga Indonesia Bahagia Bumi Bintaro Permai.

Gerakan Kesehatan Ibu dan Anak (GKIA). (2016). 1001 Langkah Selamatkan Ibu \& Anak. Jakarta: Puspa Swara 
Kumra, S., Simpson, R., Burke, R. J. (2014). The Oxford Handbook of Gender in Organizations. Oxford: OUP Oxford.

Maturidi, A. D. (2012). Metode Penelitian Teknik Informatika. Yogyakarta: CV Budi Utama.

Sutarti, T. \& Irawan, E. (2017). Kiat Sukses Meraih Hibah Penelitian Pengembangan. Yogyakarta. CV Budi Utama. 